\title{
Volatile Composition of Macedonian and Hungarian Wines Assessed by GC/MS
}

\section{Violeta Ivanova, Marina Stefova,}

\section{Borimir Vojnoski, Trajče Stafilov, Ildiko}

Bíró, Anita Bufa, Attila Felinger \& Ferenc Kilár

Food and Bioprocess Technology An International Journal

ISSN 1935-5130

Volume 6

Number 6

Food Bioprocess Technol (2013) 6:1609-1617

DOI 10.1007/s11947-011-0760-y

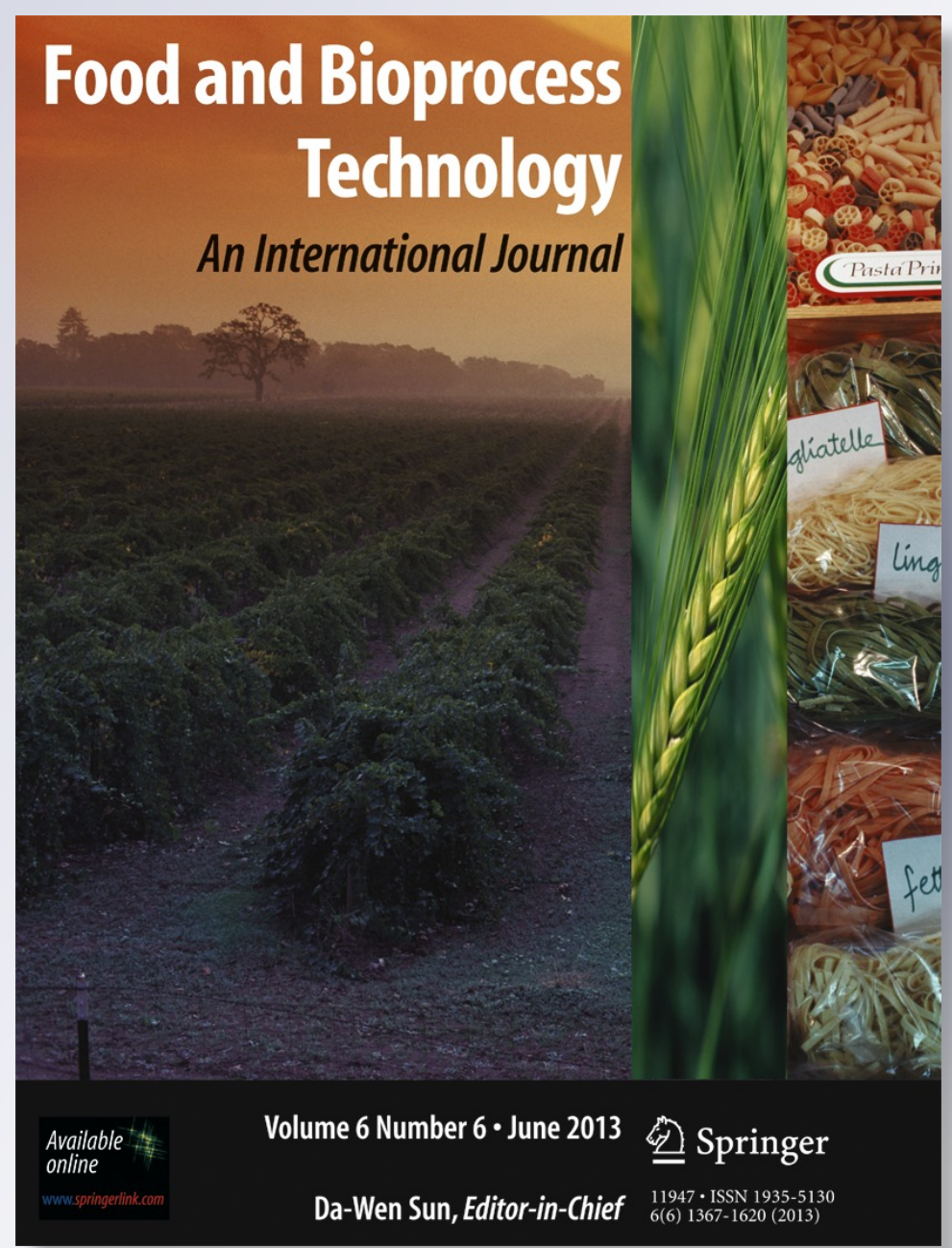

望 Springer 
Your article is protected by copyright and all rights are held exclusively by Springer Science+Business Media, LLC. This e-offprint is for personal use only and shall not be selfarchived in electronic repositories. If you wish to self-archive your article, please use the accepted manuscript version for posting on your own website. You may further deposit the accepted manuscript version in any repository, provided it is only made publicly available 12 months after official publication or later and provided acknowledgement is given to the original source of publication and a link is inserted to the published article on Springer's website. The link must be accompanied by the following text: "The final publication is available at link.springer.com". 


\title{
Volatile Composition of Macedonian and Hungarian Wines Assessed by GC/MS
}

\author{
Violeta Ivanova $\cdot$ Marina Stefova $\cdot$ Borimir Vojnoski • \\ Trajče Stafilov • Ildiko Bíró • Anita Bufa • \\ Attila Felinger · Ferenc Kilár
}

Received: 29 April 2011 /Accepted: 9 December 2011 /Published online: 5 January 2012

(C) Springer Science+Business Media, LLC 2012

\begin{abstract}
The volatile composition of eight varietal wines Vranec, Merlot, Cabernet Sauvignon, Temjanika and Chardonnay from the Republic of Macedonia, and Portugieser, Kékfrankos and Tokaji Aszú from Hungary has been characterized by means of gas chromatography/mass spectrometry technique. The wine volatile compounds were extracted in dichloromethane, and the extracts were concentrated under nitrogen. Forty-four volatile compounds have been identified mainly using the NIST mass spectral library and by comparison with the available standards used for quantification as well. Differences between the wines were noted for
\end{abstract}

\section{Ivanova $(\square)$}

Faculty of Agriculture, University "Goce Delčev"- Štip,

Krste Misirkov bb,

2000 Štip, Republic of Macedonia

e-mail: violeta.ivanova@ugd.edu.mk

\section{Stefova $\cdot$ T. Stafilov}

Institute of Chemistry, Faculty of Natural Sciences

and Mathematics, Ss "Cyril and Methodius" University,

1000 Skopje, Arhimedova 5,

Republic of Macedonia

B. Vojnoski

Department for Enology, Institute of Agriculture,

Sts "Cyril and Methodius" University,

Aleksandar Makedonski bb,

1000 Skopje, Republic of Macedonia

\section{Bíró • A. Bufa • F. Kilár}

Institute of Bioanalysis, Faculty of Medicine, University of Pécs,

Szigeti útja 12,

7624 Pécs, Hungary

\section{A. Felinger $\cdot$ F. Kilár}

Department of Analytical and Environmental Chemistry,

Faculty of Sciences, University of Pécs,

Ifjúság útja,

7624 Pécs, Hungary a number of compounds, such as a higher concentration of 1-pentanol and 2-phenyl ethanol in the red wines. Monoterpenes, linalool and terpineol were detected only in the white wines, Chardonnay and Tokaji. Macedonian red wines were characterized by a higher level of alcohols, while the Hungarian wines contained a higher amount of esters, fatty acids and lactones. A statistical treatment including one-way ANOVA, followed by a Tukey's test has been performed in order to ascertain possible significant differences between the wines studied, and principal component analysis to study the possible grouping of the wines.

Keywords Wine - GC/MS · Volatile compounds . Liquid-liquid extraction

\section{Introduction}

The volatile composition is a very important factor affecting the wine aromatic attributes and hence its quality. Some volatile compounds originate from the grapes where they are synthesized, but most of them are formed during the process of grape must fermentation and afterwards during the storage of wines. Different parameters influence the regional character, the presence and the aroma composition of the grapes, such as grape varietal characteristics, light intensity, temperature, soil, climate, degree of maturation, cultivation practices, etc. (Zoecklein et al. 1998; Bureau et al. 2000; Lee et al. 2007; Skinkis et al. 2010). Furthermore, the techniques applied during the wine making, such as crushing, pressing, fermentation temperature, maceration, yeast strain, $\mathrm{SO}_{2}$, wine dealcoholisation and supercritical extraction, also affect the extraction of the grape aroma compounds and their content in the juice (Daudt and Ough 1973; Shinohara and Watanabe 1981; Cheynier et al. 1989; 
Marais 1998; Epifanio et al. 1999; Macedo et al. 2008; Belisario-Sánchez et al. 2011). During wine ageing under different conditions, the volatile composition could be changed due to appearance of some volatiles that could decline the wine aroma quality.

Different groups of volatile compounds have been identified in grapes and wines, including alcohols, esters, aldehydes, lactones, terpenes and phenols. The monoterpenes are compounds which have a high impact on the wine aroma, contributing significantly to the flavour of wine. Estimation of the aroma compounds is usually performed by gas chromatography/mass spectrometry (GC/MS), as a highly efficient separation technique for volatiles' analysis and for characterization of the wine bouquet. Moreover, GC/MS is also suitable for quantification purposes, using polar column for separation of the components, since it is more sensitive for analysis of components present in a low concentration, as well as in a complex matrices, as wine (Riu-Aumatell et al. 2011; Weldegergis et al. 2011; Gonzalez-Alvarez et al. 2011; Xi et al. 2011; Castro-Vázquez et al. 2011). The volatile compounds are usually extracted by different methods, such as solid-phase extraction (López et al. 2002; Hernanza et al. 2008), solid-phase microextraction (Martorell et al. 2002), stir bar sorptive extraction (Díez et al. 2004; Coelho et al. 2009), or liquid-liquid extraction methods using organic solvents (Moio et al. 1995; Ortega-Heras et al. 2002; Andujar-Ortiz et al. 2009) before the gas chromatographic analysis.

There are not much data available for the Hungarian wines (Vas et al. 1998; Miklosy et al. 2000, 2004; Toth-Markus et al. 2002) as well as for the aroma profile of the Macedonian wines. Moreover, no previous research has been performed on the volatile composition of the Vranec variety, which is the most widespread and economically the most important cultivar in the Republic of Macedonia (Ivanova et al. 2011), and also in Montenegro (autochthonous variety) and Serbia. Therefore, the aim of the present work was to characterize for the first time the main volatile components making the aroma profile of the local red wine Vranec and local white wine Temjanika, and compare them to those of a widely grown and recognized cultivars, such as Cabernet Sauvignon and Merlot, as well as Chardonnay, produced from the grape varieties grown in the Tikveš wine region in Republic of Macedonia. Furthermore, the volatile profile of the red wines Portugieser and Kékfrankos produced in Hungary has also been examined for the first time in this study.

\section{Materials and Methods}

Wine Samples

Wines Vranec, Merlot, Cabernet Sauvignon, Temjanika and Chardonnay were kindly supplied by the Tikveš Winery from Kavadarci (Tikveš wine region), Republic of Macedonia, while the wines Portugieser and Kékfrankos (from the Villány wine region) and Tokaji Aszú (considered to be among the first three of the best wines in the World) were purchased from the local market in Pécs, Hungary. All the wine samples were from the same vintage, 2008, and were kept at $4{ }^{\circ} \mathrm{C}$ before the analysis.

\section{Chemicals and Reagents}

The reference compounds were 2-phenyl ethanol, ethyl nonanoate, butyrolactone, tyrosol and 1-octanol (used as an internal standard), purchased from Fluka (St. Louis, MO, USA). A commercial solution of 24 aliphatic hydrocarbons (C8-C32) in a hexane, used for calculation of the linear retention indices, was from Supelco (Bellefonte, PA, USA). Dichloromethane was obtained from Merck (Darmstadt, Germany). Ten milligrams of 2-phenyl ethanol, ethyl nonanoate, buturolactone and tyrosol were dissolved in $10 \mathrm{~mL}$ of dichloromethane to obtain the standard stock solutions.

\section{Sample Preparation}

Volatile compounds were isolated by a liquid-liquid extraction, following the procedure reported by Moio et al. (1995). Thus, $50 \mathrm{~mL}$ of wine, containing $200 \mu \mathrm{L}$ internal standard of 1-octanol in hexane $(500 \mu \mathrm{g} / \mathrm{L})$ were placed in a glasscapped Erlenmeyer flask. The extraction was performed with $25 \mathrm{~mL}$ dichloromethane under the continuous stirring in an ice bath for $30 \mathrm{~min}$ on a magnetic stirrer. Then, the mixture was centrifuged at $3,000 \mathrm{rpm}$ for $15 \mathrm{~min}$ at a temperature of $2-4{ }^{\circ} \mathrm{C}$. Once the phases have been separated, the dichloromethane layer was evaporated under a nitrogen stream to approximately $200 \mu \mathrm{L}$ volume of the extract and then, a volume of $1 \mu \mathrm{L}$ was injected into the GC/MS system. All extractions were carried out in a triplicate.

\section{GC/MS Analysis}

The apparatus used for the analysis of volatile compounds in the wines was an Agilent 5975 Mass Spectrometer directly coupled to an Agilent 6890N Gas Chromatograph (Agilent, Santa Clara, USA). The polar capillary column for separation of the compounds was a Carbowax type from Agilent, $30 \mathrm{~m} \times 0.25 \mathrm{~mm}$ ID $\times 0.25 \mu \mathrm{m}$ film thickness. The temperature program was as follows: $40{ }^{\circ} \mathrm{C}$ for $3 \mathrm{~min}$, then raised with $3{ }^{\circ} \mathrm{C} / \mathrm{min}$ up to $180{ }^{\circ} \mathrm{C}$, and then raised with $2{ }^{\circ} \mathrm{C} / \mathrm{min}$ up to $260^{\circ} \mathrm{C}$ and kept for $10 \mathrm{~min}$. The splitless mode was used for sample injection. The injector temperature was set at $240{ }^{\circ} \mathrm{C}$, and the detector temperature at $250{ }^{\circ} \mathrm{C}$. The carrier gas was He with flow rate of $1 \mathrm{~mL} / \mathrm{min}$. A mass range of 50-400 m/z was recorded at $1 \mathrm{scan} / \mathrm{s}$. 


\section{Statistical Analysis}

For each of the 44 detected compounds, one-way analysis of variance, followed by the Tukey's test, was performed in order to ascertain a possible significant differences between the studied wines. A principal component analysis (PCA) was applied to study the possible grouping of the wines. STATISTICA 6.0 (StatSoft Inc., USA) software was used for the statistical treatments.

\section{Results and Discussion}

Alcohols are secondary products mainly produced during the yeast metabolism. In our work, 15 alcohols have been identified in the analysed red and white wines (Table 1). The total concentration of the alcohols ranged from 32.3 to $45.5 \mathrm{mg} / \mathrm{L}$ for the red wines and 17.6 to $20.9 \mathrm{mg} / \mathrm{L}$ for the white wines. The highest alcohol content was found in the Merlot wine. Similar amounts were found in the Vranec, Portugieser and Kékfrankos wines, which were not significantly different $(p>0.05)$, confirmed by the one-way analysis of variance. Concerning the white wines, the highest total alcohol content was obtained in the Chardonnay wine, while Temjanika and Tokaji wines contained similar amounts (the difference was not statistically significant, $p$ $>0.05$ ). This volatile fraction was mainly composed of 1 pentanol and 2-phenyl ethanol (the most important phenolderived higher alcohol), as the major components in the overall volatile content of the wines, formed by the yeast, from the sugars or from the amino acids. It has been found that 1-pentanol and 2-phenyl ethanol were present in a highest concentration in Merlot and Chardonnay wines, while their content was not significantly different $(p>0.05)$ between the red wines Vranec and Portugieser, Portugieser and Kékfrankos, and the white wines Temjanika and Tokaji. Tyrosol is the other important phenolic alcohol in the wines. Considerable amounts of this compound, which is usually formed from tyrosine during the alcoholic fermentation, have been found in four wines. However, only slight differences were found for tyrosol $(p>0.05)$ in the Merlot and Cabernet Sauvignon, and also in the Vranec, Protugieser and Kékfrankos wines $(p>0.05)$. Tyrosol was not detected in the white wines. Considerable amounts of isobutyl alcohol and 3-(methylthio)-1-propanol were found in all wines, which are formed during the catabolic pathway from their corresponding amino acids, valine and methionine, respectively (Li et al. 2008; Perestrelo et al. 2006). Alcohols may be formed from the metabolic activity of spoilage yeasts and bacteria, or from the grape-derived aldehydes, through reaction of a reductive denitrification of the amino acids (Chen 1978). The composition of amino acids depends on the grape variety and fruit maturity (Stines et al. 2000).
Thus, it is expected that different amounts of alcohols could be formed in the wines produced from different grape varieties, as it was observed in this study. Furthermore, the compounds 3-methyl-1-pentanol, 3-ethoxy-1-propanol and 2,6-dimethyl-3,7-octadiene-2,6-diol were not detected in the red wines, while E-3-hexanol was not present in the white wines. In general, it was noticed that the alcohols were the largest group of the volatile compounds, accounting for more than $60-70 \%$ of the volatile constituents of the wines analysed. In general, differences between the red wines were observed, whereas the Merlot and Cabernet Sauvignon had high content of alcohols, while Vranec was not very different from the Hungarian wines Portugieser and Kékfrankos. The Chardonnay wine was characterized with the highest alcohol content among the white wines studied.

Esters comprise another important family of aroma compounds in wine. These compounds are formed by esterification of alcohols and acids followed by water molecule elimination (Perestrelo et al. 2006). Because the wine contains a large number of different alcohols and acids, a wide variety of esters could be formed. In our study, 18 esters were detected in the wines analysed (Table 1). Kékfrankos and Chardonnay wines possessed the highest amount of total esters in comparison to the other red and white wines, respectively. Diethyl succinate, giving the fruity aromatic impact, was the main contributor to this class of volatile compounds in red wines, followed by isoamyl acetate, ethyl butanoate and diethyl malate. In the white wines, isoamyl acetate was the dominant component of this volatile class, followed by ethyl caprylate and ethyl caproate. The presence of diethyl succinate and ethyl malate in the wines is strongly related to the alcoholic fermentation. In fact, the red wines contained a higher amount of diethyl succinate compared to the white wines, whereas the Kékfrankos and Portugieser had the highest content of this component. Hexyl acetate and ethyl palmitate were not detected in the red wines, and the ethyl palmitate was not present in the Tokaji wine, either. Ethyl esters of the fatty acids generally possess a very pleasant odour contributing to the fruity flavour, especially for the white wines (Marais and Poll 1980). In our study, the white wines contained a higher amount of ethyl caproate and ethyl caprylate, suggesting that the fruity note is stronger to that one of the red wines. The acetate esters, such as isoamyl acetate and phenylethyl acetate, possessing sensory impact described as 'banana and apple', were detected in the wines in higher concentrations in the white wines compared to the red ones.

Terpenes are another family of volatile components, which characterize the aroma of different grape varieties and their corresponding wines. A wide number of terpenes are particularly identified as important contributors to the aroma of the "Muscat" and related cultivars (Marino et al. 1995; Fenoll et al. 2009). In the present work, only three 


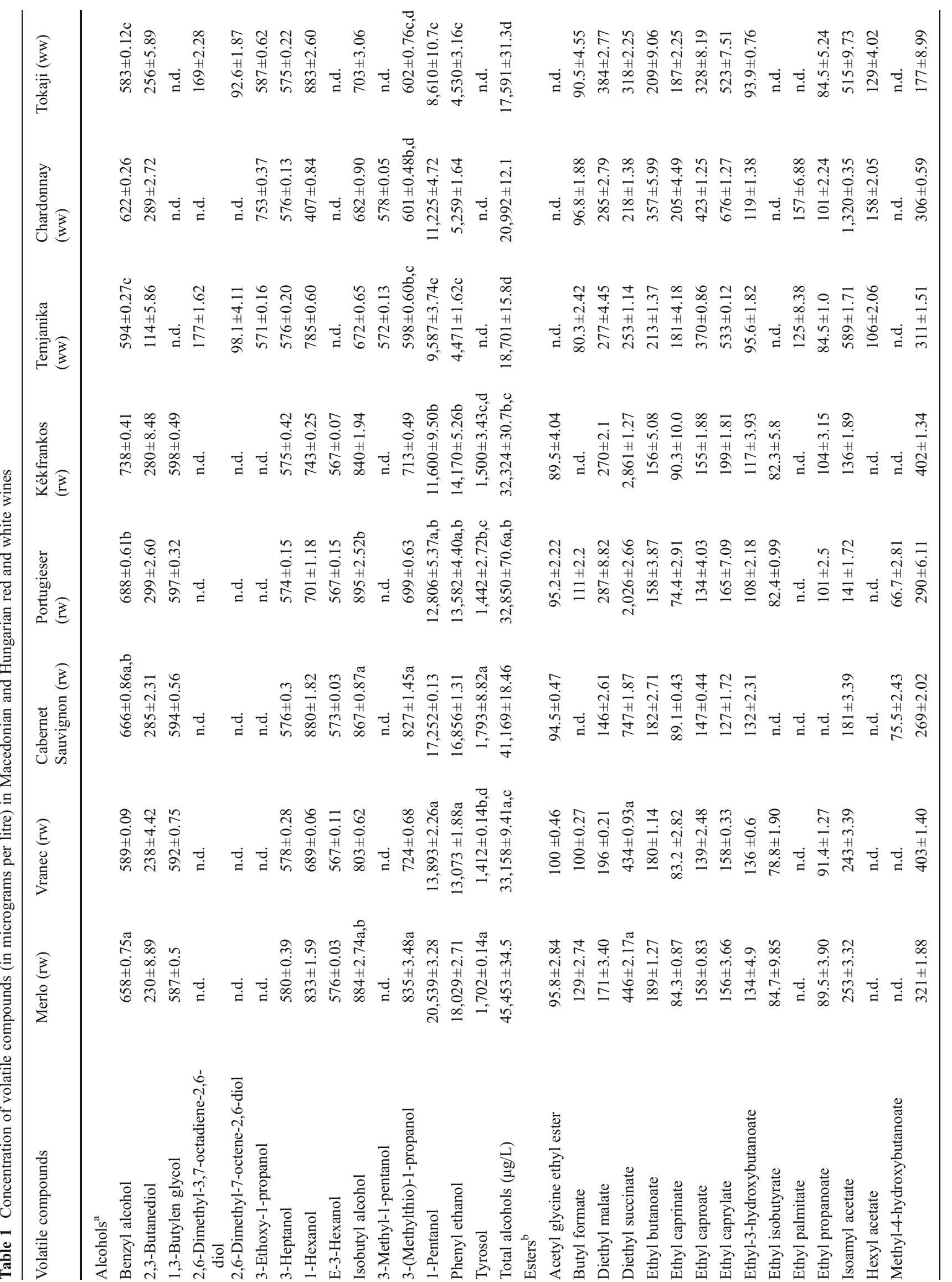




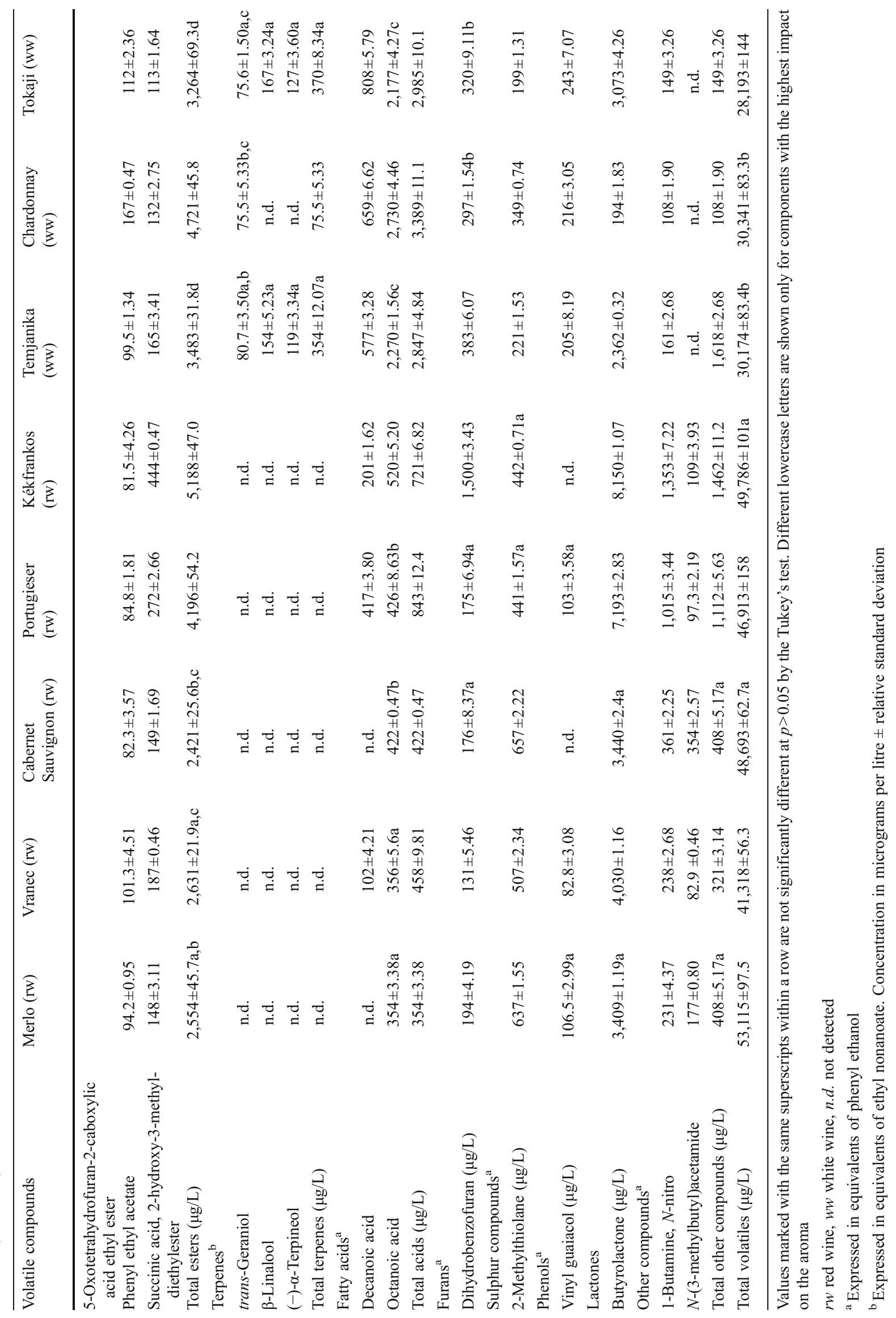


terpenes, trans-geraniol, $\beta$-Linalool and $(-)$ - $\alpha$-terpineol were detected in the white wines, Temjanika and Tokaji Aszú, and only trans-geraniol was confirmed to be present in the Chardonnay wine (Table 1). The presence of these terpenes, hence, was expected for Temjanika, since this variety belongs to the family of Muscat de Frontignan, a well-known cultivar characterized with relatively high terpene content. No significant difference was found between the Temjanika and Tokaji wines looking at the content of trans-geraniol, $\beta$-Linalool and (-)- $\alpha$-terpineol, suggesting that these terpenes play similar role in the overall flavour and aroma of both wines.

Regarding the lactones, considerable amounts of butyrolactone was found in the wines, especially in the Portugieser and Kékfrankos (Table 1). The content of butyrolactone depends on the grape variety and maceration (Bueno et al. 2003). It is derived from the amino or organic acids during the fermentation. Furthermore, this compound typically arises from oak, as an additional source of lactones. Thus, a higher amount of butyrolactone found in the Portugieser and Kékfrankos, compared to the other wines studied, could be an indication of a wine's oak ageing.

Volatile components belonging to the group of fatty acids, such as octanoic and decanoic acids, were also detected and quantified in the wines (Table 1). These fatty acids may arise during the fermentation as secondary products of the yeast metabolism, and they could inhibit the alcoholic fermentation (Lafon-Lafourcade et al. 1984). Significant differences between the red and white wines were found for the total content of the fatty acids, present in remarkably higher amounts in the white wines. Decanoic acid was not detected in Merlot and Cabernet Sauvignon wines.

Other class of aroma compounds is volatile phenols, such as vinyl guaiacol, which was found in some of the wines (Table 1). Vinyl guaiacol results from the decarboxylation of the non-flavonoid compound ferulic acid (phenolic acid) during fermentation, and it has a spicy character (Chatonnet et al. 1993). However, the white wines had a higher amount of this volatile compared to the red wines Merlot, Vranec and Portugieser, while vinyl guaiacol was not detected in the Cabernet Sauvignon and Kékfrankos wines.

The volatile sulphuric compounds are derived from the sulphur-containing amino acids during the microbial transformations, or from the elemental sulphur used for protection of the wine from different processes. The only sulphur compound identified in the wines was 2-methylthiolane, found in a higher level in the red wines (Table 1). Among the other volatile compounds found in wines, only $N$-(3-methylbutyl) acetamide was found in the red wines (Table 1).

A PCA was carried out using the whole set of data in order to discover the similarities or differences among the Macedonian and Hungarian red and white wines and to specify the main volatile components, which could differentiate the wines. The projection of the wine samples on the first two principal components $(73.52 \%$ of the total variability) showed that the red wines were clearly separated from the white wines. The red wines were located in the positive part of the PC1 (57.71\%), and the white wines were placed in the negative part of the PC1 (Fig. 1a). The main components responsible for the differences in red and white wines were 2-phenyl ethanol, 1-pentanol, 3-heptanol and isobutyl alcohol, positively correlated to the $\mathrm{PC} 1$ and specific for the red wines. Furthermore, parameters that discriminated the white wines were isoamyl acetate, ethyl caprylate, ethyl caproate, ethyl caprinate, diethyl malate, vinylguiacol, octanoic and decanoic acids, negatively contributing to PC1.

With regard to PC2 $(15.81 \%)$, the red wine classification was achieved between the samples from both countries: the Hungarian red wines Kékfrankos and Portugieser were clearly separated from the Macedonian ones, Vranec, Cabernet Sauvignon and Merlot. The principal components responsible for the differences in the volatile composition of the wines produced in the different regions, Macedonia and Hungary, were also determined. Thus, benzyl alcohol, butyrolactone, diethyl succinate and dihydrobenzofuran were specific to the Hungarian wines, while tyrosol, 3heptanol and 1-pentanol were found as the main volatile components in the Macedonian wines. Regarding the white wines, there was no such clear difference in the volatile composition of the wines from the two countries, even though Tokaji Aszú was slightly separated and located in the positive part of the PC2, while the Macedonian wines, Temjanika and Chardonnay, were located in the negative part of PC2.

\section{Conclusion}

A total of 44 volatile compounds were determined by GC/MS in red and white wines produced in the Republic of Macedonia and Hungary. Considering all the detected volatiles, alcohols and esters were the main contributors to the overall flavour and aroma of the wines, which made up to $60-80 \%$ and $5-20 \%$ of the total level of volatiles, respectively. The Merlot wine contained higher amount of volatile compounds compared to the other red wines. The Macedonian red wines were characterized by higher level of alcohols, while the Hungarian wines contained higher amount of esters, fatty acids and lactones. The high amount of butyrolactone in Kékfrankos and Portugieser could be an indication of the ageing of these wines in oak barrels. Terpenes, which significantly contribute to the overall wine aroma, were only detected in the white wines. 
a

PC1 vs. PC2 $(73.52 \%)$

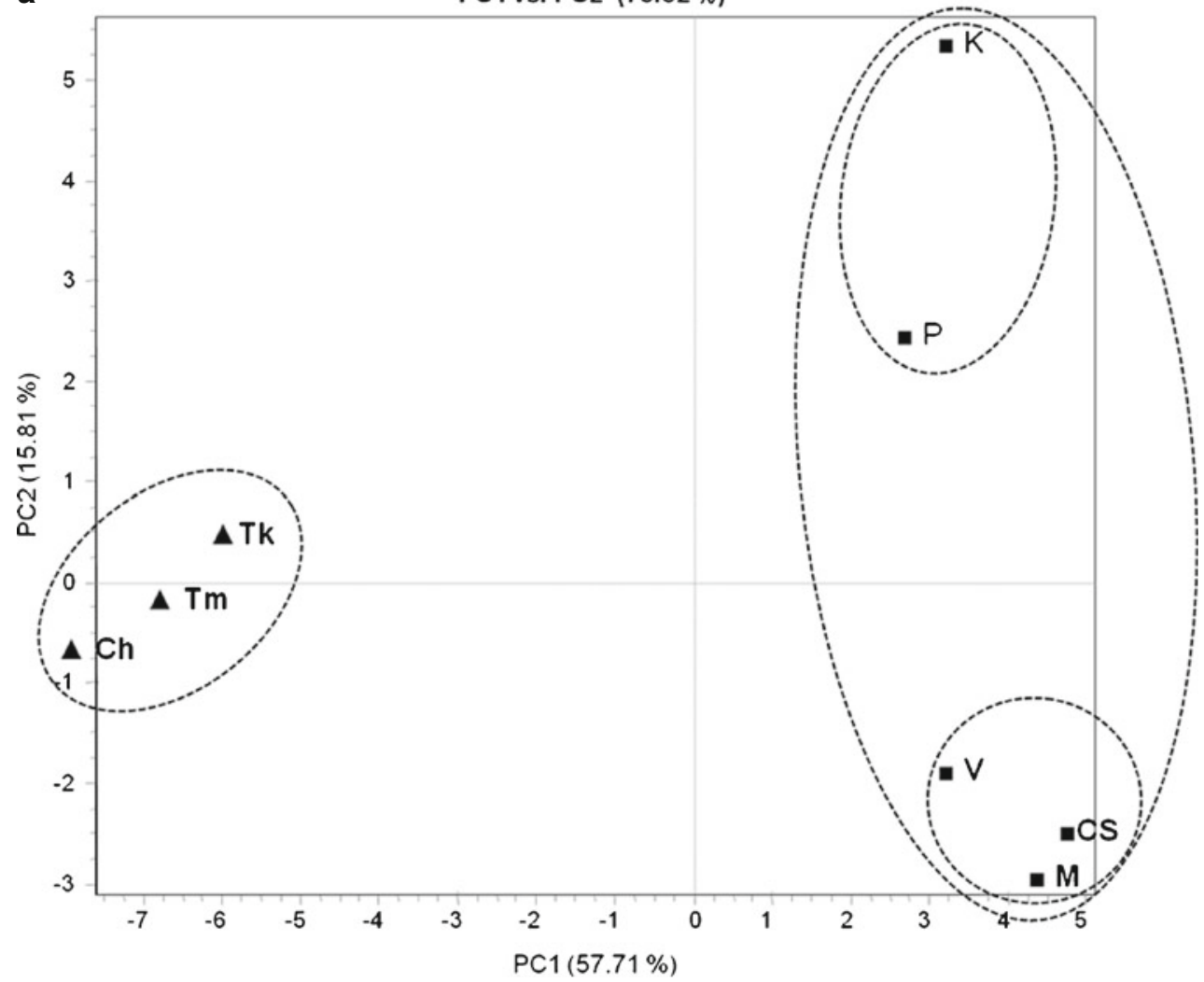

b

Correlation scatterplot, PC1 vs. PC2 (73.52 \%)

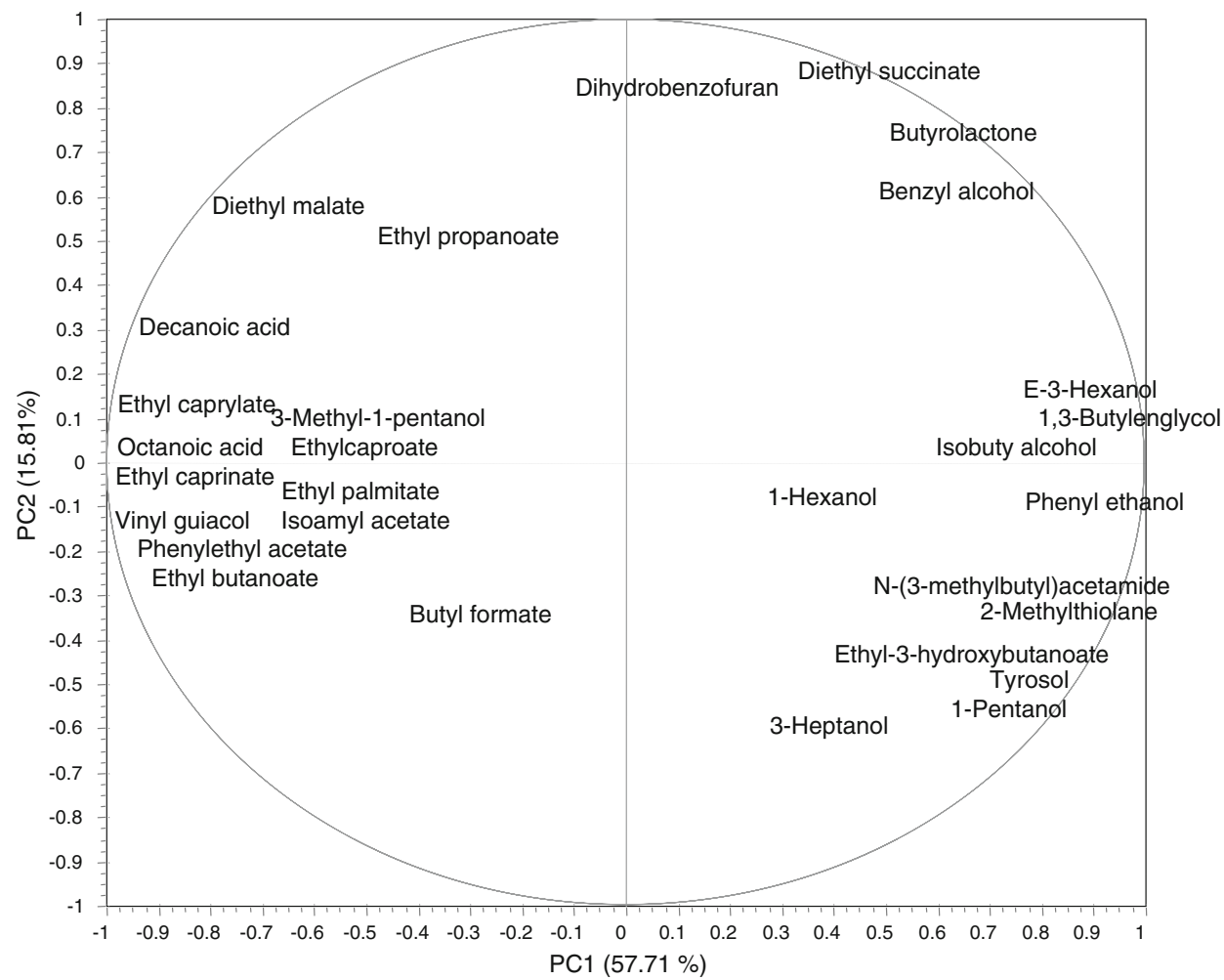

Fig. 1 Principal component score plot (a) and correlation scatter plot (b) of the variables with $\mathrm{PC} 1$ and $\mathrm{PC} 2$ based on the volatile composition of the red (filled squares $-K$ Kékfrankos, $P$ Portugieser, $V$ Vranec, $M$
Merlot, CS Cabernet Sauvignon) and white (filled triangles - Tk Tokaji, $T m$ Temjanika, Ch Chardonnay) wines. Only the main components responsible for the differences in the wines are presented in Fig. $1 \mathrm{~b}$ 
Acknowledgments The authors would like to thank Mr. Kire Trajkov from the Tikveš Winery (Kavadarci, R. Macedonia) for supplying the Macedonian red and white wine samples. This work was supported by a grant from the CEEPUS, CII-HU-0010-03-0809 Network, covering the study stay of V.I. in Pécs, Hungary, which is gratefully acknowledged.

\section{References}

Andujar-Ortiz, I., Moreno-Arribas, M. V., Martín-Álvarez, P. J., \& Pozo-Bayón, M. A. (2009). Analytical performance of three commonly used extraction methods for the gas chromatography-mass spectrometry analysis of wine volatile compounds. Journal of Chromatography A, 1216, 7351-7357.

Belisario-Sánchez, Y. Y., Taboada-Rodríguez, A., Marín-Iniesta, F., Iguaz-Gainza, A., \& López-Gómez, A. (2011). Aroma recovery in wine dealcoholization by SCC distillation. Food and Bioprocess Technology. doi:10.1007/s11947-011-0574-y.

Bueno, J. E., Peinado, R., Moreno, J., Medina, M., Moyano, L., \& Zea, L. (2003). Selection of volatile aroma compounds by statistical and enological criteria for analytical differentiation of musts and wines of two grape varieties. Journal of Food Science, 68, 158-163.

Bureau, S., Razungles, A., \& Baumes, R. (2000). The aroma of muscat of Frogtignan grapes: Effect of the light environment of vine or bunch on volatiles and glycoconjugates. Journal of the Science of Food and Agriculture, 80, 2012-2020.

Castro-Vázquez, L., Alañón, M. E., Calvo, E., Cejudo, M. J., DíazMaroto, M. C., \& Pérez-Coello, M. S. (2011). Volatile compounds as markers of ageing in Tempranillo red wines from La Mancha D.O. stored in oak wood barrels. Journal of Chromatography A, 1218, 4910-4917.

Chatonnet, P., Dubourdieu, D., Boidron, J., \& Lavigne, V. (1993). Synthesis of volatile phenols by Saccharomyces cerevisiae in wines. Journal of the Science of Food and Agriculture, 62, 191202.

Chen, E. C. H. (1978). The relative contribution of Ehrlich and biosynthetic pathways to the formation of fusel alcohols. Journal of the American Society of Brewing Chemists, 35, 39-43.

Cheynier, V. F., Rigaud, J., Souquet, J. M., Barillère, J. M., \& Moutounet, M. (1989). Effect of pomace contact and hyperoxidation on the phenolic composition and quality of Grenache and Chardonnay wines. American Journal of Enology and Viticulture, 40, $36-42$.

Coelho, E., Coimbra, M. A., Nogueira, J. M. F., \& Rocha, S. M. (2009). Quantification approach for assessment of sparkling wine volatiles from different soils, ripening stages, and varieties by stir bar sorptive extraction with liquid desorption. Analytica Chimica Acta, 635, 214-221.

Daudt, C. E., \& Ough, C. S. (1973). Variations in some volatile acetate esters formed during grape juice fermentation. Effects of fermentation temperature, $\mathrm{SO}_{2}$, yeast strain, and grape variety. American Journal of Enology and Viticulture, 24, 130-135.

Díez, J., Domínguez, C., Guillén, D. A., Veas, R., \& Barroso, C. G. (2004). Optimisation of stir bar sorptive extraction for the analysis of volatile phenols in wines. Journal of Chromatography A, 1025, 263-267.

Epifanio, S., Gutierrez, A., Santamaría, M.-P., \& López, R. (1999). The influence of enological practices on the selection of wild yeast strains in spontaneous fermentation. American Journal of Enology and Viticulture, 50(2), 219-224.

Fenoll, J., Manso, A., Hellín, P., Ruiz, L., \& Flores, P. (2009). Changes in the aromatic composition of the Vitis vinifera grape Muscat Hamburg during ripening. Food Chemistry, 114, 420-428.
Gonzalez-Alvarez, M., Gonzalez-Barreiro, C., Cancho-Grande, B., \& Simal-Gandara, J. (2011). Relationships between Godello white wine sensory properties and its aromatic fingerprinting obtained by GC-MS. Food Chemistry, 129, 890-898.

Hernanza, D., Galloa, V., Recamales, Á. F., Meléndez-Martínezb, A. J., \& Herediab, F. J. (2008). Comparison of the effectiveness of solid-phase and ultrasound-mediated liquid-liquid extractions to determine the volatile compounds of wine. Talanta, 76, 929-935.

Ivanova, V., Dörnyei, Á., Márk, L., Vojnoski, B., Stafilov, T., Stefova, M., et al. (2011). Polyphenolic content of Vranec wines produced by different vinification conditions. Food Chemistry, 124, 316325.

Lafon-Lafourcade, S., Geneix, C., \& Ribéreau-Gayon, P. (1984). Inhibition of alcoholic fermentation of grape must by fatty acids produced by yeasts and their elimination by yeast ghosts. Applied and Environmental Microbiology, 47, 1246-1249.

Lee, S. H., Seo, M. J., Riu, M., Cotta, J. P., Block, D. E., Dokoozlian, N. K., et al. (2007). Vine microclimate and norisoprenoid concentration in Cabernet Sauvignon grapes and wines. American Journal of Enology and Viticulture, 58, 291-301.

Li, H., Tao, Y. S., Wang, H., \& Zhang, L. (2008). Impact odorants of Chardonnay dry white wine from Changli County (China). European Food Research and Technology, 227, 287-292.

López, R., Aznar, M., Cacho, J., \& Ferreira, V. (2002). Determination of minor and trace volatile compounds in wine by solid-phase extraction and gas chromatography with mass spectrometric detection. Journal of Chromatography A, 966, 167-177.

Macedo, S., Fernandes, S., Lopes, J. A., de Sousa, H., Pereira, P. J., Carmelo, P. J., et al. (2008). Recovery of wine-must aroma compounds by supercritical $\mathrm{CO}_{2}$. Food and Bioprocess Technology, 1, 74-81.

Marais, J. (1998). Effect of grape temperature, oxidation and skin contact on Sauvignon Blanc juice and wine composition and wine quality. South African Journal Enology and Viticulture, 19(1), 1016.

Marais, J., \& Poll, H. J. (1980). Effect of storage time and temperature on the volatile composition and quality of dry white table wines. Vitis, 19, 151-164.

Marino, N. C., Tamames, E. L., \& Jares, C. M. G. (1995). Contribution to the study of the aromatic potential of three Muscat Vitis vinifera varieties: Identification of new compounds. Food Science and Technology International, 1, 105-116.

Martorell, N., Martí, M. P., Mestres, M., Busto, O., \& Guasch, J. (2002). Determination of 4-ethylguaiacol and 4-ethylphenol in red wines using headspace-solid-phase microextraction-gas chromatography. Journal of Chromatography A, 975, 349-354.

Miklosy, E., Kalmar, Z., Polos, V., \& Kerenyi, Z. (2000). Study of volatile aroma components in young Tokaji Aszu wines by GCMS. Chromatographia, 51, S305-S308.

Miklosy, E., Kalmar, Z., \& Kerenyi, Z. (2004). Identification of some characteristic aroma compounds in noble rotted grape berries and Aszu wines from Tokaj by GC-MS. Acta Alimentaria, 33(3), 215226.

Moio, L., Chambellant, E., Lesschaeve, I., Issanchou, S., Schlich, P., \& Etievant, P. X. (1995). Production of representative wine extracts for chemical and olfactory analysis. Italian Journal of Food Science, 7(3), 265-278.

Ortega-Heras, M., González-SanJosé, M. L., \& Beltrán, S. (2002). Aroma composition of wine studied by different extraction methods. Analytica Chimica Acta, 458, 85-93.

Perestrelo, R., Fernandes, A., Albuquerque, F. F., Marques, J. C., \& Camara, J. S. (2006). Analytical characterization of the aroma of Tinta Negra Mole red wine: Identification of the main odorants compounds. Analytica Chimica Acta, 563, 154-164.

Riu-Aumatell, M., Vargas, L., Vichi, S., Guadayol, J. M., LópezTamames, E., \& Buxaderas, S. (2011). Characterisation of volatile 
composition of white salsify (Tragopogon porrifolius L.) by headspace solid-phase microextraction (HS-SPME) and simultaneous, distillation-extraction (SDE) coupled to GC-MS. Food Chemistry, 129, 557-564.

Shinohara, T., \& Watanabe, M. (1981). Effects of fermentation conditions and aging temperature on volatile ester contents in wine. Agricultural and Biological Chemistry, 45, 2645-2651.

Skinkis, P. A., Bordelon, B. P., \& Butz, E. M. (2010). Effects of sunlight exposure on berry and wine monoterpenes and sensory characteristics of Traminette. American Journal of Enology and Viticulture, 61, 147-156.

Stines, A. P., Grubb, J., Gockowiak, H., Henschke, P. A., Hoj, P. B., \& van Heeswick, R. (2000). Proline and arginine accumulation in developing berries of Vitis vinifera L. in Australian vineyards: Influence of vine cultivar, berry maturity and tissue type. Australian Journal of Grape and Wine Research, 6, $150-158$.
Toth-Markus, M., Magyar, I., Kardos, K., Banszky, L., \& Maraz, A. (2002). Study of Tokaji Aszu wine flavour by solid phase microextraction method. Acta Alimentaria, 31(4), 343-354.

Vas, G., Gal, L., Harangi, J., Dobo, A., \& Vekey, K. (1998). Determination of volatile aroma compounds of Blaufrankisch wines extracted by solid-phase microextraction. Journal of Chromatographic Science, 36(10), 505-510.

Weldegergis, B. T., de Villiers, A., \& Crouch, A. M. (2011). Chemometric investigation of the volatile content of young South African wines. Food Chemistry, 128, 1100-1109.

Xi, Z-m, Tao, Y-s, Zhang, L., \& Li, H. (2011). Impact of cover crops in vineyard on the aroma compounds of Vitis vinifera L. cv Cabernet Sauvignon wine. Food Chemistry, 127, 516-522.

Zoecklein, B. W., Wolf, T. K., Marcy, J. E., \& Jasinski, Y. (1998). Effect of fruit zone leaf thinning on total glycosides and selected aglycone concentrations of Riesling (Vitis vinifera L.) grapes. American Journal of Enology and Viticulture, 49, 35-43. 